\title{
THE CHARACTERISTICS OF THE MAXIMUM FLOW IN THE UPPER BASIN OF CRIŞUL NEGRU RIVER
}

\author{
Dan-Mircea MIHALEA ${ }^{1,2}$, Ruth PERJU ${ }^{3}$, Iulia LUPU ${ }^{3}$, \\ Mihaela UNGUREANU ${ }^{1}$, Anamaria Liana L $\breve{A Z U R A N}\left(\right.$ AXINTE) ${ }^{1}$
}

DOI: 10.24193/AWC2020_15

\begin{abstract}
The paper aims to highlight the characteristics of the maximum flow in the Upper Basin of Crișul Negru River. The catchment area has $947 \mathrm{~km} 2$ and it is located in the Western Carpathians, upstream Beiuș city. In order to achieve the proposed purpose, the hydrological and meteorological data recorded between 1973-2018 at five gauging stations located in the study area (on the main watercourse and on some important tributaries) were statistically analyzed, namely mean monthly temperatures and amounts of precipitation, mean daily discharges, maximum monthly and annual discharges and hydrographs of the largest floods. The interannual variability of the maximum annual discharges shows downward trends, but statistically significant at only two of the analyzed measurement points (Ștei g.st. on Crişul Băița River, with 5\% significance level and Pietroasa g.st. on Crișul Pietros River, with $10 \%$ significance level). Seasonally, the maximum annual discharges are most frequently recorded during winter and spring (between $60 \%$ and $70 \%$ of cases in the analyzed period). The mean daily discharges were analyzed to identify the floods/periods of high flow and their seasonal and annual frequency at the five gauging stations (a flood/period of high flow being considered any value that exceeds three times the mean multiannual discharge): the most frequent are the spring floods $(32 \%-41 \%)$, induced by heavy rainfall or associated rainfall snowmelt events and the winter floods (18\%-23\%), mostly caused by sudden snowmelt, sometimes associated with rainfall events. The summer rainfall induced floods represent $21 \%$ to $26 \%$ of the total and the lowest frequency is recorded in autumn at all five gauging stations. For the floods with the largest peak discharge (exceeding the average of the maximum annual discharges), the characteristic elements were determined, of which the average values of the form coefficients are between 0.22 and 0.27 and the average total durations between 1 and 12 days.
\end{abstract}

Keywords. Maximum flow, variability, frequency, flood, Upper Basin of Crişul Negru River

\section{INTRODUCTION}

The study of the maximum flow characteristics is part of the process of understanding the hydrological regime and determining the water resources in a river

${ }^{1}$ University of Oradea, Faculty of Geography, Tourism and Sport, Doctoral School of Geography (mirceamihalea@yahoo.com,umihaela59@yahoo.com, anamaria_lazuran@yahoo.com)

${ }^{2}$ Crișuri Water Basin Administration

${ }^{3}$ National Institute of Hydrology and Water Management (ruth.perju@hidro.ro, iulia.lupu@hidro.ro) 
basin. At the same time, the analysis of the hydrological data series highlights the correlations or the interdependence of the hydrological or hydro-climatic parameters. The present paper aims to emphasize the characteristics of the maximum flow and of the floods in the Upper Basin of the Crișul Negru River, located in the western part of Romania, in the Western Carpathians and the adjacent depressional area. Regarding the geographical characteristics (mainly the hydrological and climatic features) of the study area, several studies were carried out, with broader topics or areas considered, among which: IMH, 1968; Diaconu, 1971; Ujvari, 1972; Berindei, 1977; Gaceu, 2005a; Gaceu, 2005b; Mustățea, 2005, or focused on Crișul Negru River Basin: Alexe, 2004; Mihalea and Botău, 2019.

\section{STUDY AREA: POSITION AND PHYSICO-GEOGRAPHICAL CHARACTERISTICS}

The Crişul Negru River Basin has a total area of $4645 \mathrm{~km}^{2}$, of which approximately $4237 \mathrm{~km}^{2}$ on the Romanian territory, in the western part of Romania. It is part of the Crișuri hydrographic system and has in its vicinity: Crișul Repede River Basin in the northern part, Someșul Mic River Basin in the eastern part, Crișul Alb River Basin in the southern part and the border with Hungary (where it flows in Crișul Alb River) in the western part (Fig. 1).

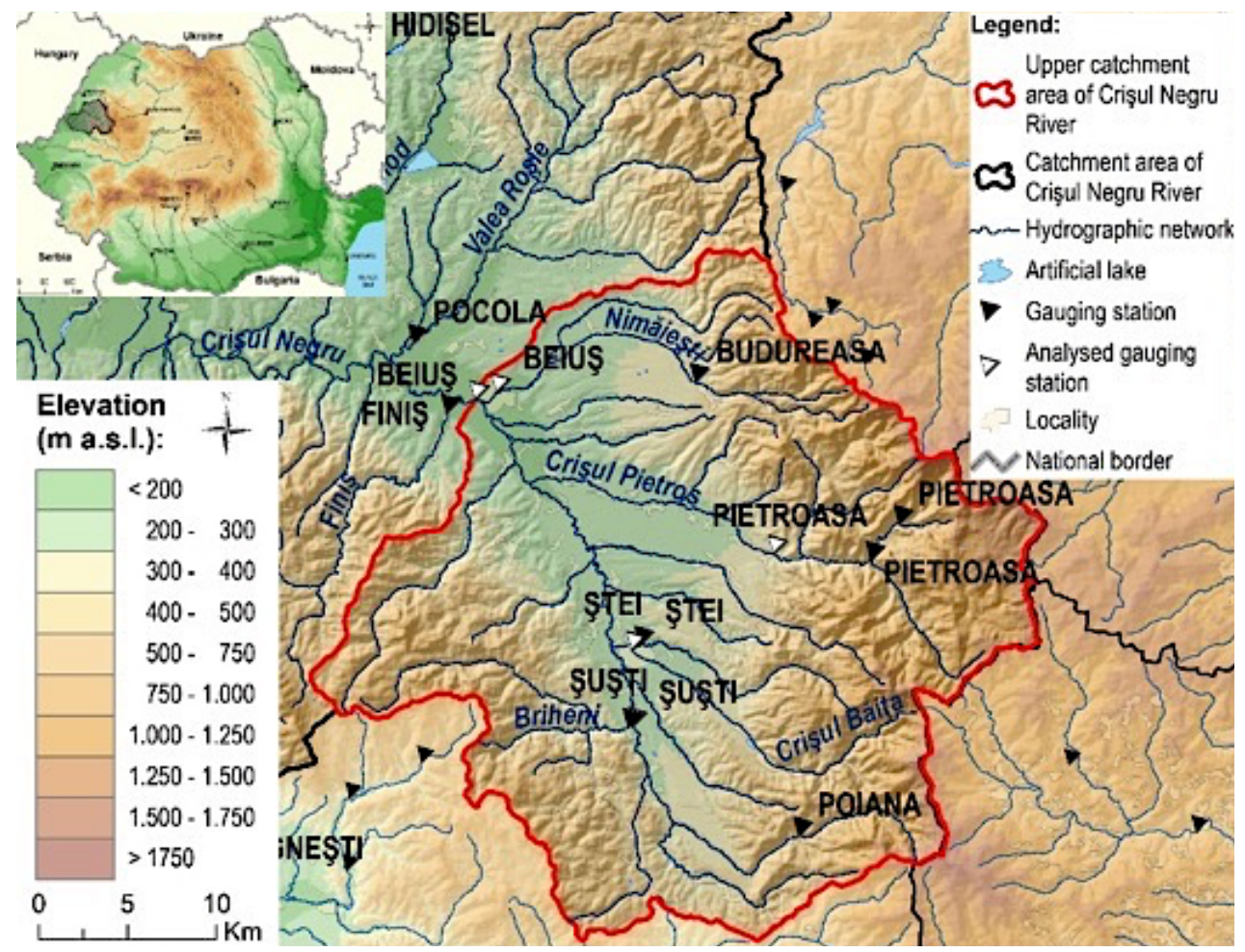

Fig. 1. The Upper Basin of Crișul Negru River: location, limits, hypsometry, hydrographic and hydrometric networks 
Based on the morphological and hydrographical characteristics and the climatic particularities, the Crișul Negru River Basin can be divided into three segments: the upper basin, up to the Beiuș city (downstream of the confluence with the Nimăiești River), draining an area of $940 \mathrm{~km}^{2}$ (according to the state water cadastre - Atlasul Cadastrului Apelor din România, 1992), the middle basin up to the exit of Crișul Negru from the Borz-Șoimi Gorge $\left(558 \mathrm{~km}^{2}\right)$ and the lower basin, up to the border with Hungary, with an area of $2739 \mathrm{~km}^{2}$. The study focuses on the upper basin, which drains the western slopes of the Western Carpathians, more precisely the slopes of the Bihor and Vlădeasa Mountains in the eastern part of the basin, the Codru-Moma Mountains to the South and the Pădurea Craiului Mountains to the North. The tributaries of the upper part of Crișul Negru converge from these orographic units or from the piedmont hills to the lower area of the Beiuș depression. The average altitude of the study area is $581 \mathrm{~m}$, the highest point is $1694 \mathrm{~m}$ (Cârligate Peak), and the lowest altitude is $180 \mathrm{~m}$ (near Beiuş city) (Fig. 1).

Geologically, the mountainous area of the basin is mainly formed by crystalline formations and old eruptive rocks, but the limestones are also present (Padiş Plateau, Vaşcău Plateau, parts of Pădurea Craiului Mountains), thus the areas with impermeable or slightly permeable rocks alternate with those with permeable rocks. The piedmont hills are formed by Neogene sedimentary rocks and, in the depressional area, the Jurassic and Cretaceous sedimentary deposits (sandstones, clays, conglomerates) are predominant (IMH, 1968).

From climatic point of view, the studied area has a temperate-continental climate with weak Mediterranean influences (IMH, 1968). The position of the hydrographic basin in the western part of the country in the direction of the humid western air masses, as well as the morphological characteristics (altitude, slopes' exposure etc.) impose the climatic characteristics of the study area, namely the vertical variations of the climatic parameters and the zonal particularities. The mean multiannual air temperature varies from $8.0^{\circ} \mathrm{C}$ at high altitudes to $11.0^{\circ} \mathrm{C}$ in the depressional area. The mean value for the entire upper basin of $9.5^{\circ} \mathrm{C}$. The mean multiannual amount of precipitation is $1050 \mathrm{~mm}$, with approx. $1200 \mathrm{~mm}$ in the highest areas and approx. $850 \mathrm{~mm}$ in the lower areas (Beiuș city). The highest precipitation amounts are recorded during spring and early summer (June), while the driest month is February.

The hydrological regime of Crișul Negru River corresponds to the Western-Carpathian type (Diaconu, 1971) with a distribution of seasonal discharges of winter-summer-autumn type. The drainage is strongly influenced by the river flow source (groundwater, surface water flow), by the regime and variability of the climatic factors and by the physicogeographical conditions. The maximum flow, which is the consequence of the rich water resource resulting from the snow melting and from the heavy rainfall (Pișotă et al., 2010), can be manifested as periods of high waters, representing longer periods in which the water discharges are continuously above the multiannual average (Sorocovschi, 2002), but most often as floods, which represent peak moments in the evolution of the flow of a river, meaning sudden increases of the water level and discharge of a river, followed by their usually slower decreases (Pișotă et al., 2010). 
The factors that generate the maximum flow and determine its characteristics are climatic (solar radiation and processes determined by its temporal variations), geological (petrography, structure), morphological (slope exposure, relief energy, slopes, density of relief fragmentation), pedological (soil types and their characteristics), related to the land cover, but also anthropic (through hydrotechnical constructions and changes of the land cover). The main climatic parameters that determine the appearance and manifestation of the maximum flow are the precipitation and the air temperature, which imposes the type of rainfall (liquid or solid) and the accumulation/melting of the snow layer. The variations in temperature on short periods during winter can cause both, the sudden snowmelt and the shift of solid precipitation to liquid precipitation, the pluvio-nival floods being the hydrological response. On the other hand, during the warm season, the significant amounts of precipitation lead to long periods with high flows and summer floods. The droughts are specific from the end of the summer until the first part of the winter, phenomenon that is more intense in the last several years.

The geological characteristics have influence on the share of river flow source, so that in the karstic regions, where the transfer of groundwater from a basin to another takes place, the river flow is sustained by the groundwater all year long (river basins of Boga, Valea Galbenă, Crișul Pietros, Briheni, Crișul Văratec, Tărcăița), while in the regions with less permeable rocks, the flow follows closely in its variations the precipitation and snowmelt regime. The morphology, especially the altitude, the steep slopes and the density of the hydrographic network, favors the rapid drainage of high flows, thus, in terms of maximum flow, the floods are more frequent than the high-water phenomena.

\section{DATA AND METHODS}

In order to achieve the proposed purpose, hydrological data series, climatic data and cartographic data were used. The climatic and hydrological data were obtained from the archive of the Crișuri Water Basin Administration, namely from Beiuș Hydrological Station (HS).

The hydrological data refer to maximum monthly and annual discharges, mean daily discharges and hourly discharges during the largest floods (hydrographs of the floods), recorded at gauging stations (g.st.) part of the national hydrometric network in the period 1973-2018.

The climatic data (daily temperatures and precipitation, data on the snow layer) were used to determine the causes of the floods and were taken from the selected gauging stations, as well as from the meteorological stations in the analyzed region (Stâna de Vale, Ștei, Vlădeasa, Holod, Dumbrăvița de Codru).

The cartographic data refer to the topographic and thematic maps (geological, hydrographical) of the study area, as well as to digitized data, processed in GIS environment.

The quantitative monitoring of watercourses in the Upper Basin of Crișul Negru River is carried out through three gauging stations on the main collector and eight gauging stations located on its tributaries. These are established between 1889 and 1986 (Table 1). For a conclusive statistical analysis of the data, a common observation period was selected, so that the data series to be long enough, for as 
many gauging stations as possible and to include the maximum historical discharges recorded. Thus, the analysis was performed for 5 gauging stations (two on the main collector and three on its tributaries), considering the common period 1973-2018.

Table 1. The analyzed gauging stations, morphological and hydrological characteristics of the river basins related to them (F-surface of the river basin, Havg - average altitude of the river basin; Qmean -mean multiannual discharge, Qmax avg - average of the annual maximum discharges, calculated for the period 1973-2018)

\begin{tabular}{|c|l|l|c|c|c|c|c|}
\hline No. & \multicolumn{1}{|c|}{ River } & $\begin{array}{c}\text { Gauging } \\
\text { station }\end{array}$ & $\begin{array}{c}\text { Year of } \\
\text { establishment }\end{array}$ & $\begin{array}{c}\mathbf{F} \\
\left(\mathbf{k m}^{\mathbf{2}}\right)\end{array}$ & $\begin{array}{c}\text { Havg } \\
(\mathbf{m M N})\end{array}$ & $\begin{array}{c}\text { Qmean } \\
\left(\mathbf{m}^{\mathbf{3}} / \mathbf{s}\right)\end{array}$ & $\begin{array}{c}\text { Qmax avg } \\
\left(\mathbf{m}^{\mathbf{3}} \mathbf{/ s}\right)\end{array}$ \\
\hline 1 & Crișul Negru & Șuști & 1950 & 137 & 617 & 2.26 & 33.9 \\
\hline 2 & Crișul Negru & Beiuș & 1889 & 940 & 581 & 14.0 & 222 \\
\hline 3 & Crișul Băița & Ştei & 1961 & 65 & 796 & 1.26 & 22.3 \\
\hline 4 & $\begin{array}{l}\text { Crișul } \\
\text { Pietros }\end{array}$ & Pietroasa & 1951 & 158 & 972 & 4.29 & 66.0 \\
\hline 5 & Nimăiești & Beiuș & 1973 & 108 & 502 & 1.69 & 42.9 \\
\hline
\end{tabular}

The maximum monthly and annual discharges were statistically processed to determine characteristic values and trends in their inter-annual variability. Trends and degree of statistical significance were determined with the Mann-Kendall test (Salmi et al., 2002).

In order to identify the monthly, seasonal and annual frequency of the floods, the mean daily discharges were analyzed, considering as a threshold any value greater than at least three times the average multi-annual discharge represents a flood (the consecutive values being counted as a single event) (Réméniéras, 1999).

In order to highlight the main features of the floods, the characteristic elements/parameters were calculated for all the simple (singular), pluvial or pluvionival floods, recorded at the selected gauging stations and having maximum discharges higher than the average of the maximum annual flow.

\section{RESULTS AND DISCUSSIONS}

\subsection{Characteristics of maximum flow}

The inter-annual variability of the maximum annual discharges at the five gauging stations analyzed shows periods/years with exceptional maximum flow at all gauging stations analysed (e.g.: 1980, 1981, 1989, 1995, 2000, 2001), fact that shows that these maximum discharges are generalized floods, propagated throughout the basin, on both, the main collector and on most of its tributaries (Fig. 3).

The maximum annual discharges from the five selected gauging stations show descendant trends, due to the lower amounts or intensities of precipitation recorded over the last 15 years. However, the significance level of the trends is of only $5 \%$ and $10 \%$ for Ștei g. st., respectively Pietroasa g.st. and statistically not significant for the other gauging stations, which may be due to a cyclicality of the maximum flow, depending on the rainfall regime (rainy years - dry years).

The extreme annual maximum discharges produced only in some sub-basins of the studied area are the result of convective rainfalls, recorded on small areas. 

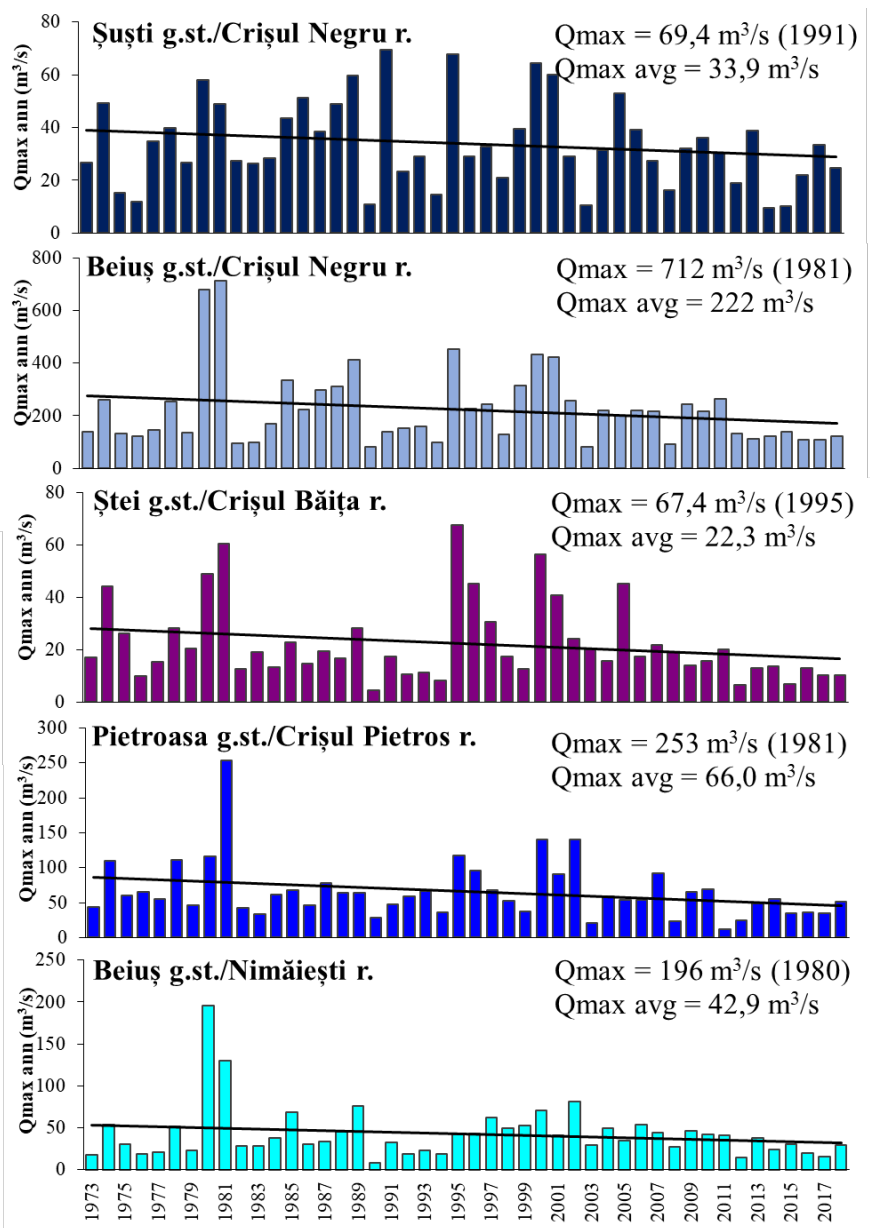

Fig. 3. The maximum annual discharges and their linear trend at gauging stations within the upper basin of Crișul Negru River for the period 1973-2018 (Qmax - maximum discharge recorded during the observation period; Qmax avg - average of annual maximum discharges)
Regarding the maximum annual flow regime (namely the variability of the average of maximum monthly discharges), the richest flow is noted in the spring months, with the tendency to remain in the same value range until midsummer (July). The averages of the monthly maximums then decrease until October, where they tend to increase towards the last month of the year, highlighting a high frequency of the floods in December, due to the circulation of warmer and wetter oceanic air masses (Fig. 4a).

At the Pietroasa g. st., on the Crișul Pietros River, the averaged values of maximum monthly discharges vary in a smaller interval than the other gauging stations, especially in the summer and spring months, compared to the autumn months, when high values are maintained. This particularity is due to the limestone rocks in which the water is stored and then ensures a relatively high flow al year. The minimum value is in February, when the prolonged periods with low rainfall amounts and/or with snowfall and low temperatures lead to the depletion of the water resources stored underground.

The maximum monthly discharges show the highest values in March-April, JulyAugust and December (Fig. 4b).

The analysis of the largest floods recorded for the determination of their monthly and seasonal frequencies was performed considering (i) the maximum annual discharges (annual floods) and (ii) the maximum monthly discharges with values above the average of annual maximum discharges (as a threshold to identify all the significant floods). 


\subsection{Monthly and seasonal frequency of floods}

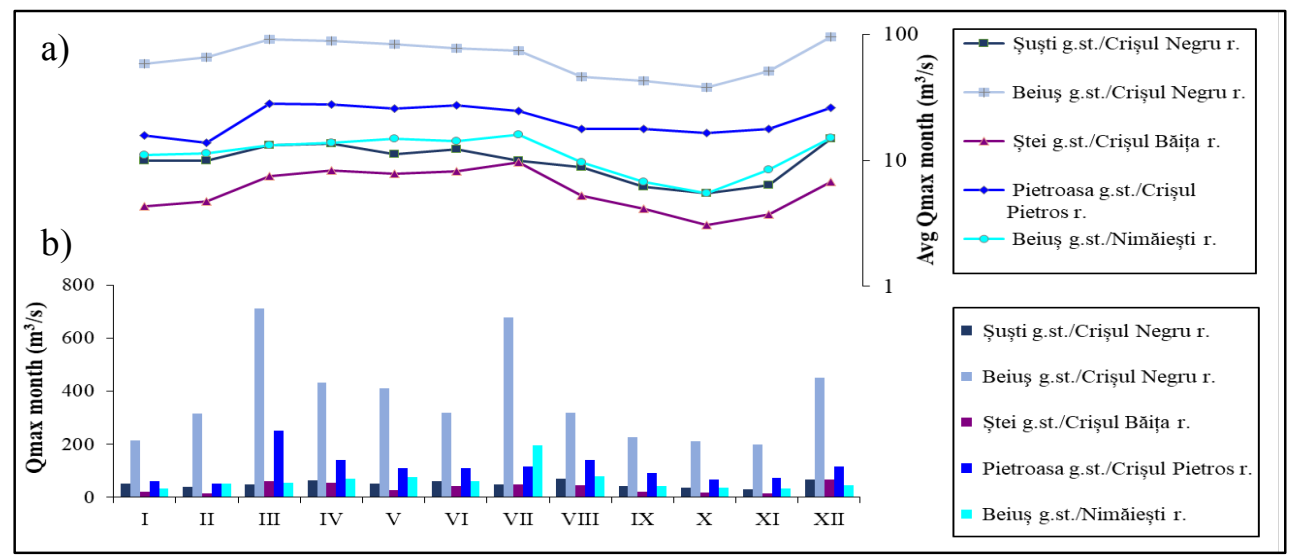

Fig. 4. The maximum annual flow regime (the average of maximum monthly discharges) represented on a logarithmic scale (a) and the maximum monthly discharges (b) at gauging stations in the Upper Basin of Crisul Negru River (1973-2018)

The annual floods have the highest frequencies in May-July, but also in December and, on the main collector, in January (Table 2). Seasonally, the maximum annual discharges occur most frequently in spring and/or summer on tributaries. The annual winter floods have high frequencies on the main course, up to $33 \%$, due to the partial or total melting of the snow layer during the cold season. It is noteworthy the small frequencies of extreme events in winter at the Pietroasa and Ştei g. st., a fact caused by the presence of the karst that does not allow the accumulation of the snow layer for long periods and, consequently, large nival or pluvio-nival floods due to the snowmelt.

Table 2. Monthly and seasonal frequency of annual floods at the gauging stations within the Upper Basin of Crişul Negru River (1973-2018)

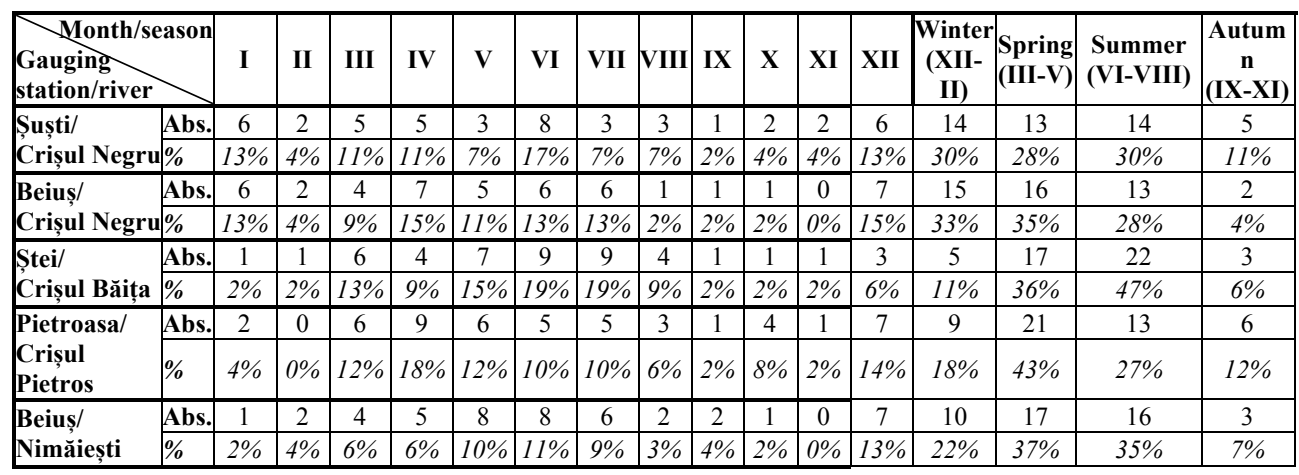

In autumn, the annual floods are the rarest, with frequencies between 4\% (at Beiuș g.st., on Crișul Negru River) and 12\% in the limestone basin of Crișul Pietros (Fig. 5). 
To determine the frequency of all the floods recorded at the five gauging stations, mean daily discharges were analyzed, any value exceeding three times the mean multiannual discharge being considered a flood (except the values above this threshold which were recorded in consecutive days).

In general, at annual level, the highest frequencies of the floods are observed in the same years as the annual floods propagated throughout the basin (Fig. 3). At monthly level, compared with the frequency of annual floods, the analysis based on mean daily discharges shows a shift earlier in spring, with maximum frequencies in March, April, July and December.

Analyzing the data on snow layer in the basin and the air temperatures, two periods were identified based on the cause of flood occurrence: May-November pluvial floods, December-April - nivo-pluvial floods. The pluvial floods are predominant for the gauging stations with karst, with steep slopes, high mean altitudes, early and early/fast melting of the snow stock (Pietroasa and Ștei g. st. with $52 \%$ of all events). On the main collector and on the other tributaries, the mixed pluvio-nival floods ( $54 \%-57 \%$ of the total events) are predominant (Table 3$)$.

Table 3. Absolute and procentual frequency of floods and the maximum number of floods (seasonal and by type) at gauging stations within the Upper Basin of the Crișul Negru River (1973-2018)

\begin{tabular}{|c|c|c|c|c|c|c|c|c|c|}
\hline \multirow{2}{*}{\multicolumn{3}{|c|}{ Gauging station/river }} & \multirow{2}{*}{$\begin{array}{l}\text { Winter } \\
\text { (XII-II) }\end{array}$} & \multirow{2}{*}{$\begin{array}{l}\text { Spring } \\
\text { (III-V) }\end{array}$} & \multirow{2}{*}{$\begin{array}{l}\text { Summer } \\
\text { (VI-VIII) }\end{array}$} & \multirow{2}{*}{$\begin{array}{c}\text { Autumn } \\
\text { (IX-XI) }\end{array}$} & \multicolumn{2}{|c|}{ Floods } & \multirow{2}{*}{$\begin{array}{c}\text { Total } \\
(1973-2018)\end{array}$} \\
\hline & & & & & & & $\begin{array}{l}\text { Pluvial } \\
(\text { V-XI) }\end{array}$ & $\begin{array}{c}\text { Pluvio-nival } \\
\text { (XII-IV) }\end{array}$ & \\
\hline \multirow{3}{*}{\begin{tabular}{|l|} 
Suști// \\
Crișul Negru \\
\end{tabular}} & \multirow{2}{*}{$\begin{array}{l}\text { Total no. } \\
\text { floods }\end{array}$} & Abs. & 80.0 & 87.0 & 55.0 & 31.0 & 108.0 & 145 & 253 \\
\hline & & $\%$ & $32 \%$ & $34 \%$ & $22 \%$ & $12 \%$ & $43 \%$ & $57 \%$ & $100 \%$ \\
\hline & \multicolumn{2}{|c|}{$\begin{array}{l}\text { Max. no. floods } \\
\text { (year of } \\
\text { occurrence) }\end{array}$} & $7(2010)$ & $7(2006)$ & $7(1980)$ & $4(2002)$ & 11 (1974) & $9(2006)$ & $13(1980)$ \\
\hline \multirow{3}{*}{$\begin{array}{l}\text { Beiuss// } \\
\text { Crișul Negru }\end{array}$} & \multirow{2}{*}{$\begin{array}{l}\text { Total no. } \\
\text { floods }\end{array}$} & Abs. & 99.0 & 128.0 & 75.0 & 52.0 & 164.0 & 190 & 354 \\
\hline & & $\%$ & $28 \%$ & $36 \%$ & $21 \%$ & $15 \%$ & $46 \%$ & $54 \%$ & $100 \%$ \\
\hline & \multicolumn{2}{|c|}{$\begin{array}{l}\text { Max. no. floods } \\
\text { (year of } \\
\text { occurrence) }\end{array}$} & $6(1977)$ & $8(2006)$ & $8(1980)$ & 7 (1998) & 13 (1974) & 12 (1977) & 17 (1978) \\
\hline \multirow[b]{3}{*}{ 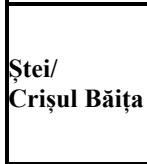 } & \multirow{2}{*}{$\begin{array}{l}\text { Total no. } \\
\text { floods }\end{array}$} & Abs. & 65.0 & 103.0 & 73.0 & 44.0 & 148.0 & 137 & 285 \\
\hline & & $\%$ & $23 \%$ & $36 \%$ & $26 \%$ & $15 \%$ & $52 \%$ & $48 \%$ & $100 \%$ \\
\hline & \multicolumn{2}{|c|}{$\begin{array}{l}\text { Max. no. floods } \\
\text { (year of } \\
\text { occurrence) }\end{array}$} & $5(2004)$ & $6(1977)$ & $8(1974)$ & 4 (1974) & 16 (1974) & $8(1977)$ & 18 (1974) \\
\hline \multirow{3}{*}{$\begin{array}{l}\text { Pietroasa/ } \\
\text { Crișul } \\
\text { Pietros }\end{array}$} & \multirow{2}{*}{\begin{tabular}{|l} 
Total no. \\
floods
\end{tabular}} & Abs. & 67.0 & 150.0 & 79.0 & 67.0 & 190.0 & 173 & 363 \\
\hline & & $\%$ & $18 \%$ & $41 \%$ & $22 \%$ & $18 \%$ & $52 \%$ & $48 \%$ & $100 \%$ \\
\hline & \multicolumn{2}{|c|}{$\begin{array}{l}\text { Max. no. floods } \\
\text { (year of } \\
\text { occurrence) }\end{array}$} & $6(2016)$ & $9(1987)$ & 7 (1974) & $6(1992)$ & 15 (1974) & $9(1987)$ & 17 (1974) \\
\hline \multirow{3}{*}{$\begin{array}{l}\text { Beiuš/ } \\
\text { Nimăiești }\end{array}$} & \multirow{2}{*}{$\begin{array}{l}\text { Total no. } \\
\text { floods }\end{array}$} & Abs. & 136.0 & 140.0 & 87.0 & 72.0 & 195.0 & 240 & 435 \\
\hline & & $\%$ & $31 \%$ & $32 \%$ & $20 \%$ & $17 \%$ & $45 \%$ & $55 \%$ & $100 \%$ \\
\hline & \multicolumn{2}{|c|}{$\begin{array}{l}\text { Max. no. floods } \\
\text { (year of } \\
\text { occurrence) }\end{array}$} & $8(1981)$ & $8(2005)$ & $9(1980)$ & 7 (1998) & $16(1980)$ & $11(1981)$ & $23(1980)$ \\
\hline
\end{tabular}

At all the gauging stations considered, the highest frequency of the floods is recorded in spring (mixed, compound floods, with $32 \%$ up to $41 \%$ of all events 
recorded). Their occurrence is dependent on the existence of the snow layer in the high mountainous region. Then it is followed, in the case of Nimăiești g. st and of the stations on the main collector, by the frequency of winter floods and by the summer floods at the other monitoring points (Fig. 6).

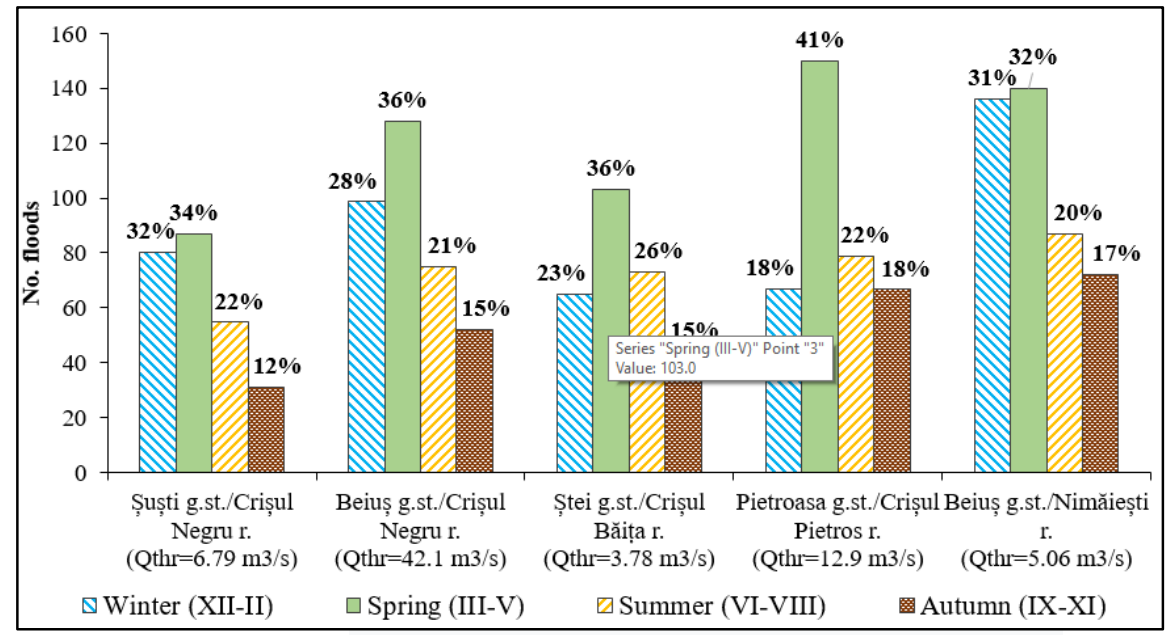

Fig. 6. Seasonal frequency (\%) of floods and threshold discharges at gauging stations within the Upper Basin of the Crișul Negru River (1973-2018)

Therefore, although the annual floods (or those with maximum discharges above the average annual maximum flows) are not very often recorded in the winter months, by adding to the analysis the "ordinary" floods, it is observed that they are, in fact, specific to the studied area even if those are not the events with the highest discharges.

\subsection{Characteristics of floods}

For the analysis of floods at the five gauging stations (for the period 1973-2018), a threshold discharge was applied, to identify the largest, most significant events. These threshold values are the average of the maximum annual discharges, any discharge exceeding it beeing selected for further analysis. After the analysis of the hydrographs, some of the maximum discharges were removed from the selection, because they occurred during periods of high waters, without being individualized as floods. Thus, for each gauging station were identified a considerable number of floods, as follows: 16 floods at Şuşti g. st. on Crişul Negru River, 16 floods at Beiuş g.st. on Crişul Negru River, 12 floods at Ştei g. st. on Crişul Băiţa River, 18 floods at Pietroasa g. st. on Crişul Pietros River and 13 floods at Beiuş g.st. on Nimăieşti River. The parameters resulted form the analysis (average, maximum and minimum values) highlight the characteristics of maximum flow in the study area, which reflects the particularities of the maximum flow and its dependence to the morphological and geological features of the hydrographic (sub-)basins (Table 4).

The average and maximum total volumes of the floods $\left(\mathrm{Wt}-\mathrm{mil} \mathrm{m}^{3}\right.$ ) are strictly related to the the catchments' surface $\left(\mathrm{km}^{2}\right)$ and shape, with average values between 
$4.02 \mathrm{mil} \mathrm{m}^{3}$ and $47.7 \mathrm{mil} \mathrm{m}^{3}$. The maximum total volume transited is, naturally, found at the downstream located gauging station and for the other stations it varies depending on the drained surface, but also depending on the petrographic and morphological features: at Pietroasa g. st. and Șuști g. st., although they have aproximately the same surface (Table 1), the mean volumes resulted are very different $\left(11.9 \mathrm{mil} \mathrm{m}^{3}\right.$, respectively $\left.7.16 \mathrm{mil} \mathrm{m}^{3}\right)$.

Table 4. The average, maximum and minimum values of the characteristic parameters of floods at gauging stations within the Upper Basin of the Crișul Negru River (Qmax -

maximum discharge, $W t$ - total volume, Ws - surface flow volume, Wb-base flow

volume, $\mathrm{Tt}$ - total duration, $\mathrm{Ti}$ - increase time, $\mathrm{Td}$ - decrease time, $\mathrm{Hs}$ - water layer, $\mathrm{Qb}$ base flow, q max - specific maximum flow, $\gamma$ - flood shape coefficient)

\begin{tabular}{|c|c|c|c|c|c|c|c|c|c|c|c|c|}
\hline Gauging station/riv & Parameter & $\begin{array}{l}Q \max \\
\left(\mathrm{m}^{3} / \mathbf{s}\right)\end{array}$ & $\begin{array}{l}\mathrm{Wt} \\
(\mathrm{mil} \\
\left.\mathrm{m}^{3}\right)\end{array}$ & $\begin{array}{l}\mathrm{Ws} \\
(\mathrm{mil} \\
\left.\mathrm{m}^{3}\right)\end{array}$ & $\begin{array}{l}\text { Wb } \\
\left(\mathrm{mil}^{3}\right. \\
\left.\mathbf{m}^{3}\right)\end{array}$ & $\begin{array}{c}\text { Tt } \\
\text { (hours) }\end{array}$ & $\begin{array}{c}\mathrm{Ti} \\
\text { (hours) }\end{array}$ & $\begin{array}{c}\text { Td } \\
\text { (hours) }\end{array}$ & $\begin{array}{c}\mathrm{Hs} \\
(\mathbf{m m})\end{array}$ & $\begin{array}{c}\mathbf{Q b} \\
\left(\mathrm{m}^{3} / \mathbf{s}\right)\end{array}$ & $\underset{\left(\mathbf{l} / \mathbf{s} / \mathbf{k m}^{2}\right)}{\mathbf{q} \max }$ & $\gamma$ \\
\hline \multirow{5}{*}{$\begin{array}{l} \\
\text { Şuști/Crișul Negru } \\
\text { (16 floods) }\end{array}$} & Average & 48.7 & 7.16 & 4.89 & 2.27 & 150.5 & 26.3 & 124.2 & 35.7 & 4.25 & 356 & 0.27 \\
\hline & Maximum & 69.4 & 13.2 & 9.42 & 4.73 & 252.0 & 48.0 & 226.0 & 68.8 & 9.4 & 507 & 0.39 \\
\hline & \begin{tabular}{|l} 
Year (month) \\
maximum
\end{tabular} & $\begin{array}{c}1991 \\
(8)\end{array}$ & $\begin{array}{c}1981 \\
(3)\end{array}$ & 2001 (4) & $1981(3)$ & $1989(5)$ & $\begin{array}{c}2001 \\
(4)\end{array}$ & $\begin{array}{l}1989 \\
(5)\end{array}$ & \begin{tabular}{|c|}
2001 \\
$(4)$
\end{tabular} & $\begin{array}{c}2000 \\
(4)\end{array}$ & $1991(8)$ & $\begin{array}{c}2000 \\
(4)\end{array}$ \\
\hline & Minimum & 35.7 & 1.79 & 1.21 & 0.575 & 60.0 & 7.0 & 48.0 & 8.85 & 1.65 & 261 & 0.16 \\
\hline & $\begin{array}{l}\text { Year (month) } \\
\text { minimum }\end{array}$ & $\begin{array}{l}1995 \\
(4)\end{array}$ & $\begin{array}{c}2006 \\
(6)\end{array}$ & $2006(6)$ & $2006(6)$ & $\begin{array}{l}1991(8) ; \\
2006(6)\end{array}$ & $\begin{array}{r}2001 \\
(12)\end{array}$ & $\begin{array}{c}2006 \\
(6)\end{array}$ & \begin{tabular}{|c|}
2006 \\
$(6)$
\end{tabular} & \begin{tabular}{r|}
1991 \\
$(10)$
\end{tabular} & 1995 (4) & $\begin{array}{c}1989 \\
(6)\end{array}$ \\
\hline \multirow{5}{*}{$\begin{array}{l}\text { Beiuș/Crișul } \\
\text { Negru } \\
\text { (16 floods) }\end{array}$} & Average & 345 & 47.7 & 34.2 & 13.6 & 158.6 & 29.0 & 129.7 & 36.3 & 24.0 & 366 & 0.25 \\
\hline & Maximum & 712 & 115 & 89.3 & 25.5 & 288.0 & 61.0 & 268.0 & 94.9 & 37.8 & 757 & 0.36 \\
\hline & \begin{tabular}{|l} 
Year (month) \\
maximum
\end{tabular} & $\begin{array}{c}1981 \\
(3)\end{array}$ & $\begin{array}{c}1981 \\
(3)\end{array}$ & 1981 (3) & $1981(3)$ & $2000(3)$ & $\begin{array}{l}2001 \\
(4)\end{array}$ & $\begin{array}{c}2000 \\
(3)\end{array}$ & $\begin{array}{c}1981 \\
(3)\end{array}$ & $\begin{array}{c}1985 \\
(5)\end{array}$ & $1981(3)$ & $\begin{array}{c}1974 \\
(6)\end{array}$ \\
\hline & Minimum & 243 & 29.0 & 19.6 & 3.9 & 96.0 & 10.0 & 67.3 & 20.9 & 8.69 & 258 & 0.18 \\
\hline & \begin{tabular}{|l} 
Year (month) \\
minimum
\end{tabular} & $\begin{array}{l}1997 \\
(7)\end{array}$ & $\begin{array}{l}2001 \\
(12)\end{array}$ & $1985(5)$ & $\begin{array}{r}2001 \\
(12)\end{array}$ & $\begin{array}{l}1974(6) ; \\
1985(5)\end{array}$ & $\begin{array}{c}1985 \\
(5)\end{array}$ & $\begin{array}{l}1974 \\
(6)\end{array}$ & $\begin{array}{c}1985 \\
(5)\end{array}$ & \begin{tabular}{|r|}
2001 \\
$(12)$
\end{tabular} & 1997 (7) & $\begin{array}{l}2001 \\
(12)\end{array}$ \\
\hline \multirow{5}{*}{$\begin{array}{l}\text { Ștei/Crișul Băița } \\
\text { (12 floods) }\end{array}$} & Average & 41.3 & 4.02 & 2.95 & 1.07 & 130.2 & 32.7 & 97.5 & 45.4 & 2.43 & 635 & 0.22 \\
\hline & Maximum & 67.4 & 7.59 & 6.00 & 2.06 & 276.0 & 81.0 & 237.0 & \begin{tabular}{|l|}
92.4 \\
\end{tabular} & 4.15 & 1037 & 0.32 \\
\hline & $\begin{array}{l}\text { Year (month) } \\
\text { maximum }\end{array}$ & $\begin{array}{r}1995 \\
(12)\end{array}$ & $\begin{array}{l}1981 \\
(3)\end{array}$ & $1981(3)$ & $\begin{array}{r}1995 \\
(12)\end{array}$ & $1989(5)$ & $\begin{array}{r}1995 \\
(12)\end{array}$ & $\begin{array}{c}1989 \\
(5)\end{array}$ & $\begin{array}{c}1981 \\
(3)\end{array}$ & \begin{tabular}{|c|}
2000 \\
$(4)$
\end{tabular} & $\begin{array}{l}1995 \\
(12)\end{array}$ & $\begin{array}{c}2005 \\
(4)\end{array}$ \\
\hline & Minimum & 22.8 & 1.02 & 0.503 & 0.385 & 26.0 & 5.5 & 17.0 & 7.74 & 1.46 & 351 & 0.13 \\
\hline & $\begin{array}{l}\text { Year (month) } \\
\text { minimum }\end{array}$ & $\begin{array}{l}2005 \\
(7)\end{array}$ & $\begin{array}{c}2005 \\
(7)\end{array}$ & 2005 (7) & 2005 & 2005 (4) & $\begin{array}{l}1975 \\
\text { (6) }\end{array}$ & $\begin{array}{l}2005 \\
(4)\end{array}$ & \begin{tabular}{|c|}
2005 \\
$(7)$
\end{tabular} & $\begin{array}{c}1975 \\
(6)\end{array}$ & 2005 (7) & $\begin{array}{l}1995 \\
(12)\end{array}$ \\
\hline \multirow{5}{*}{$\begin{array}{l}\text { Pietroasa/Crișul } \\
\text { Pietros } \\
\text { (18 floods) }\end{array}$} & Average & 99.9 & 11.9 & 8.6 & 3.3 & 133.3 & 37.4 & 95.9 & 53.3 & 6.65 & 608 & 0.25 \\
\hline & Maximum & 253 & 27.2 & 20.7 & 6.5 & 204.0 & 98.2 & 154.0 & 131.2 & 16.4 & 1601 & 0.37 \\
\hline & $\begin{array}{l}\text { Year (month) } \\
\text { maximum }\end{array}$ & $\begin{array}{r}1981 \\
(12)\end{array}$ & $\begin{array}{l}1981 \\
\text { (6) }\end{array}$ & $1981(6)$ & $1981(6)$ & $2002(5)$ & $\begin{array}{c}2010 \\
(6)\end{array}$ & $\begin{array}{c}2002 \\
(5)\end{array}$ & $\begin{array}{c}1981 \\
(5)\end{array}$ & $\begin{array}{c}2000 \\
(9)\end{array}$ & $1981(5)$ & $\begin{array}{c}1996 \\
(7)\end{array}$ \\
\hline & Minimum & 66.4 & 4.13 & 3.05 & 1.08 & 6.36 & 2.00 & 2.76 & 6.36 & 2.61 & 2.76 & 0.17 \\
\hline & $\begin{array}{l}\text { Year (month) } \\
\text { minimum }\end{array}$ & $\begin{array}{l}1993 \\
(12)\end{array}$ & $\begin{array}{l}1996 \\
\text { (6) }\end{array}$ & 1996 (6) & $1996(6)$ & $1985(5)$ & $\begin{array}{l}1996 \\
\text { (6) }\end{array}$ & $\begin{array}{c}1985 \\
(5)\end{array}$ & $\begin{array}{c}1985 \\
(5)\end{array}$ & $\begin{array}{c}2007 \\
(9)\end{array}$ & $1985(5)$ & $\begin{array}{c}2011 \\
(7)\end{array}$ \\
\hline \multirow{5}{*}{$\begin{array}{l}\text { Beiuș/Nimăiești } \\
\text { (13 floods) }\end{array}$} & Average & 56.4 & 5.3 & 4.2 & 1.2 & 109.1 & 21.0 & 88.1 & 38.5 & 3.1 & 522 & 0.25 \\
\hline & Maximum & 76.2 & 9.5 & 7.9 & 2.0 & 180.0 & 38.0 & 142.0 & 73.3 & 6.7 & 705.6 & 0.34 \\
\hline & \begin{tabular}{|l|} 
Year (month) \\
maximum
\end{tabular} & $\begin{array}{c}1989 \\
(5)\end{array}$ & $\begin{array}{c}1989 \\
(5)\end{array}$ & $1989(5)$ & $2000(4)$ & $1989(5)$ & $\begin{array}{l}1999 \\
(2)\end{array}$ & $\begin{array}{l}1989 \\
(5)\end{array}$ & \begin{tabular}{|c|}
1989 \\
$(5)$
\end{tabular} & \begin{tabular}{|c|}
2000 \\
$(4)$
\end{tabular} & $1989(5)$ & $\begin{array}{c}1974 \\
(6)\end{array}$ \\
\hline & Minimum & 44.1 & 2.4 & 1.7 & 0.6 & 72.0 & 9.0 & 55.0 & 15.5 & 1.8 & 408 & 0.16 \\
\hline & $\begin{array}{l}\text { Year (month) } \\
\text { minimum }\end{array}$ & $\begin{array}{c}2007 \\
(9)\end{array}$ & $\begin{array}{c}1998 \\
\text { (6) }\end{array}$ & & $2007(9)$ & $1974(6)$ & $\begin{array}{c}1985 \\
(5)\end{array}$ & $\begin{array}{c}2000 \\
(4)\end{array}$ & $\begin{array}{c}1998 \\
(6)\end{array}$ & \begin{tabular}{|c|}
1997 \\
$(7)$
\end{tabular} & $2007(9)$ & $\begin{array}{c}1998 \\
(6)\end{array}$ \\
\hline
\end{tabular}

Regarding the duration of the floods, the highest values are recorded on the main collector, and the lowest at Nimăiești g. st. In the karstic sub-basins (Crișul Băița and Crișul Pietros) the average increase time is greater than on the main collector, but conversely for the decrease time. The shortest durations of the analyzed floods are 
specific for May and June, and the longest durations, usually nivo-pluvial floods, are recorded in spring (March-May) and depend on the existing snow stock each year.

The shape coefficient is closely linked to the decreasing time and the amplitude of the flood (consequently, its values can vary significantly depending on the base flow identified. There were obtained average shape coefficients between 0.22 and 0.27 , with minimum values of 0.13 to 0.18 as a result of sudden melting of the snow layer in the winter (December) or of the heavy rainfall during summer (June-July).

\section{CONCLUSIONS}

The maximum flow in the study area presents particularities imposed by both, its geographical position (that determines the climatic charactertistics) and geological and morphological features. Thus, the extreme events can occur throughout the year regardless of the season, but still, with a lower frequency in autumn, mainly due to the lack of rainfall.

The inter-annual variability of the maximum annual discharges shows descending trends, but statistically not significant or with weak levels of significance, because of the alternating rainy years-dry years. Monthly, the largest floods recorded are specific in March-April, July, and, on the main collector, in December.

Regardless of the data series used (maximum annual or monthly discharges, mean daily discharges) or the thresholds for identifying the significant floods, the monthly and seasonal frequencies are similar, with the exception of winter floods (in December), when even if the frequency of annual floods is relatively low, the frequency of ordinary floods is high, due to the air masses circulation that cause sudden warming and rainfall).

Certain years stand out as periods with frequent and extreme phenomena, not just in terms of maximum discharge, but also in terms of maximum and minimum values of the characteristic parameters of floods (volumes, duration, shape coefficient) and floods frequency (e.g.: 1974, 1981, 1989, 1995, 2000, 2001).

\section{ACKNOWLEDGEMENTS}

The paper is funded by the Project 123008 , "SmartDoct - High quality programs for $\mathrm{PhD}$ students and postdoctoral researchers of the University of Oradea for increasing the relevance of research and innovation in the context of the regional economy", funded by the Human Capital Operational Program 2014-2020.

\section{REFERENCES}

1. Alexe, M. (2004), Potenţialul scurgerii medii a râurilor din bazinul Crişului Negru, Analele Universităţii din Oradea, Geografie, XII, Editura Universităţii din Oradea.

2. Berindei, I. O. (1977), Țara Beiușului. Relieful, Cercetări în geografia României, Edit. Științifică și Enciclopedică, București. 
3. Diaconu C. (1971), Râurile României-Monografie hidrologică, INMH, București.

4. Gaceu O. (2005a), Caracteristici ale temperaturii aerului în Munții Bihor și Vlădeasa, Comunicări de Geografie, IX, Universitatea din București, București, p. 189-196.

5. Gaceu O. (2005b), Clima și riscurile climatice din Munții Bihor și Vlădeasa, Edit. Universității din Oradea, Oradea.

6. Institutul de Meteorologie şi Hidrologie (IMH) (1968), Monografia hidrologică a bazinului hidrografic Crișuri, Studii de hidrologie, XXIV, IMH, București.

7. Mihalea D. M., Botău O. (2019), Influence of air temperature and precipitation on the maximum flow in the Upper Basin of the Crişul Negru, Analele Universităţii din Oradea, Seria Geografie, XXIX, no. 2/2019.

8. Mustățea A. (2005), Viituri excepționale pe teritoriul României. Geneză şi efecte, Edit. Tipografia SC "ONESTA.COM PROD 94" SRL, București.

9. Pișotă I., Zaharia L., Diaconu D. (2010), Hidrologie, Edit. Universitară, București.

10. Réméniéras G. (1999), L'hydrologie de l'ingineur, Eyrolles.

11. Salmi T., Määttä A., Anttila P., Ruoho-Airola T., Amnell T. (2002), Detecting trends of annual values of atmospheric polluants by the Mann-Kendall test and Sen's slope estimates - the Excel template application MAKESENS, Publications on Air Quality No. 31, Report code FMI-AQ, Helsinki, ISBN951-697-563-1, 35 p.

12. Sorocovschi V. (2002), Hidrologia uscatului, Edit. Casa Cărții de Știință, Cluj-Napoca.

13. Ujvari I. (1972), Geografia apelor României, Edit. Științifică, București.

14.*** (1992), Atlasul Cadastrului Apelor din România, Partea 1, Date morfohidrografice asupra rețelei hidrografice de suprafață, Ministerul Mediului, Aquaproiect S.A., Edit. ROMCART S.A., Bucureşti. 